\title{
Comparison of Prospective Teachers' Perceptions of Problem-Solving Skills in Terms of Various Variables
}

\author{
Murat Keskin \\ Afyon Kocatepe University, Afyonkarahisar, TURKEY \\ Bolvadin Vocational School
}

Received: 28 March 2021 - Accepted: 4 June 2021 - Published Online: 23 June 2021

\begin{abstract}
The study aimed to determine whether there is a difference between the perceptions of preservice teachers' problem-solving skills according to various factors. 297 pre-service teachers from Afyon Kocatepe University Faculty of Education in the province of Afyonkarahisar in Turkey participated in the study. The group hidden figures test was used to determine the cognitive styles of pre-service teachers. The problem-solving inventory was used to measure the perceptions of problem-solving skills. According to the findings, it was found that the perception of problemsolving skills of pre-service teachers was high. It was observed that the candidates also perceived themselves as having these approaches in all sub-dimensions. According to the research results, problem-solving perception does not affect the way of approaching the problem. Male and female candidates' perceptions of problem-solving skills are not directly related to gender. Candidates' perceptions vary according to the grade level.
\end{abstract}

Keywords: education, teaching, problem-solving, cognitive style.

\section{Introduction}

The most prominent feature of today's education system is that it takes the individual as a basis. Therefore, the necessity of teaching activities based on individual characteristics is an undeniable fact. Teaching methods affect the students' learning, remembering, and using their information and the ways they prefer while performing these operations. Teachers should organize teaching activities by taking students' cognitive characteristics into account. For this, they should know the cognitive features of the students well. In the dimension of planning individual activities, the concept of cognitive style especially emerges as a concept that will help teachers. It is one of the ideas that occurred due to cognitive learning theorists' research on how an individual obtains information, how he creates new knowledge, how he stores this information in permanent memory, and how he remembers it (Somyürek, 2004). Messick (1976), a cognitive style researcher, underlined those individual differences reveal a difference; He claimed that each individual determines a method for himself regarding the situations he sees, remembers, or thinks. Based on this method, he named the individual differences gained in processing, organizing, and gaining experience as cognitive style (cited in Ören, 2007). Witkin, Moore, Goodenough and Cox (1997) stated that cognitive style has a higher meaning than the classically used "personality" concept.

(C) Authors. Terms and conditions of Creative Commons Attribution 4.0 International (CC BY 4.0) apply. Correspondence: Murat Keskin, Afyon Kocatepe University, Bolvadin Vocational School, Afyonkarahisar, TURKEY. E-mail: mkeskin@aku.edu.tr. 
As a result of some researches conducted by Witkin et al. in the 1940s, it was seen that individuals use specific strategies while performing certain tasks. In these studies, it was revealed that some individuals prefer to use clues from the visual field, while others consider internal clues (Somyürek \& Yalın, 2007). As a result of experimental studies (Ataizi, 1999) using the "Group Hidden Figures Test" started to be developed by Witkin in the 1950s, Witkin et al. named individuals using internal cues as "field independent" and individuals using environmental cues as "field-dependent" (Somyürek \& Lean, 2007). These two areas, consisting of different styles, have opposite features (ALTUN, 2003). Witkin (1977) expresses the differences of cognitive field dimensions: Individuals who try to find the difference by re-examining the beings they have seen before and who tend to perceive the entities analytically are field independent. Field addicts, on the other hand, adapt passively to their environment and global fashion rules (cited in Güven, 2003).

- There is not a relationship between pre-service teachers' cognitive styles and their perception of problem-solving skills.

- There is not a relationship between pre-service teachers' gender and their perception of problem-solving skills.

- The scores the students got from the PSI total and hasty approach, thinking approach, evaluative approach, and planned approach sub-dimensions were found to be statistically significant.

- The difference between the departments in which the candidates were educated was observed in the avoidant approach and the planned approach sub-dimensions.

Based on the information obtained from research results with different approaches and techniques, the researchers have suggested many cognitive styles. However, among these cognitive styles, "Field Dependence" and "Field Independence" are the cognitive dimensions (Güven, 2003). The mentioned cognitive style dimensions are one of the sub-domains of the "Holistic-Analytical" cognitive style family, one of the cognitive style areas put forward by various researchers (Ataizi, 1999).

Figure 1. Cognitive Style Areas (created from information taken from Ataizi, (1999.)

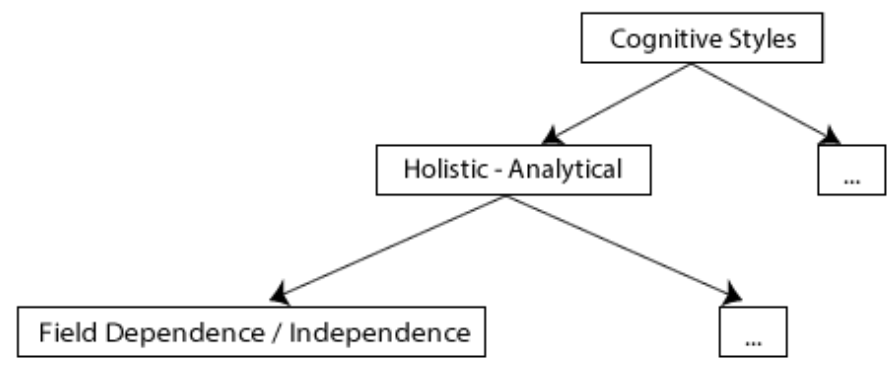

Characteristics of individuals with field-dependent and independent dimensions defined by Ramirez and Castenade (1974), Witkin and Goodenough (1981), and Saracho (1988) were compiled by Güven (2003). While field-dependent learners have characteristics such as being calm and more socially conscious, obeying the rules, and self-discipline, independent learners have high energy, prefer to work independently, and desire to be accepted in society, and so on.

Considering that individuals use specific strategies while performing certain tasks, teacher approaches gain particular importance in teaching environments. Witkin, Moore, Goodenough, and Cox (1977) identified the characteristics listed below in terms of teacher approaches. 
Field independent teachers:

- They take a more formal approach;

- They used questions as teaching tools;

- They tried to emphasize the subject with their thoughts;

- They tend to find students' mistakes and say them;

- They are not in an effort to create a positive classroom environment;

- They encourage students to apply the principles.

Field dependent teachers, on the other hand:

- They tend to interact with students more often;

- They use the questions to control what has been learned during their teaching;

- By attracting the students' attention to the subject, they encouraged them to produce their inferences;

- Avoid giving critical feedback;

- They strive to create a positive classroom environment;

- They stated that they taught the facts.

Witkin et al. (1977) stated that the concept of cognitive style is related to an individual's approach to a problem can be interpreted as revealing the importance of cognitive features in the problem-solving phase. The difference in individuals' cognitive styles with fielddependent/independent dimensions indicate the difference in their approach to a problem and naturally the difference in problem-solving skills. Therefore, when examining the dimensions of cognitive style within individual differences, it is possible to talk about the effects of cognitive style features on skills such as "problem" and "problem-solving skill".

Problem is a concept that expresses the situations that we frequently encounter at every stage of life that is complex, undesirable, and distressing to the individual (Yalçı, Tetik \& Açıkgöz, 2010). Changes in social, economic, political, and technological fields make the social structure even more complex. Individuals who cannot keep up with this complexity face many problems (Demirtaş \& Dönmez, 2008). If people can solve their problems, they can adapt to change, produce things, and contribute to society's advancement and itself.

It takes some effort to overcome the challenges we face. While expressing these efforts in problem-solving, Altun (2000) stated "knowing what to do in situations where it is not known what to do" and considered the problem-solving process as "controlled activities performed to reach a goal that is clearly designed but cannot be reached immediately". Problem-solving skill is a process of adapting to the environment in which an individual life. In this process, effective adaptation to the environment is directly proportional to problem-solving skills. However, while some problems in this adaptation process have correct and definite answers, some require knowledge related to many fields (Mertoğlu \& Öztuna, 2004).

Savaşır and Şahin (1997) re-evaluated three basic approaches that individuals show in problem-solving and identified six approaches. These approaches point out the importance of the individual's efforts to understand the problem and find solutions to the problem-solving process. In this study, said analysis of said data consider six approaches the migrants. These approaches can be listed as "hasty approach, thinking approach, avoidant approach, evaluative approach, selfconfident approach and planned approach” (cited in Yalçın, Tetik \& Açıkgöz, 2010). 
Since the problem is a state of discomfort and tension, problem-solving means eliminating this situation. It is possible to think that the problem is a situation that disrupts the mental balance of the individual and an opportunity in which he shows his cognitive skills, determination, and personal control. For this reason, solving problems will enable teachers to be more successful and self-confident individuals in educational activities, both professionally and personally.

In the light of this information, as the concepts of problem solving and cognitive style are interrelated, cognitive styles express how the problem is perceived, what strategies will be produced for its solution, in short, the individual's approach to the problem. The main difference between a field-dependent individual and a field-independent individual is the method used to perceive the situation or problem. This study compares the six sub-dimensions determined by Savaşır and Şahin (1997) from the Heppener's problem-solving skill inventory, the fielddependent/independent pre-service teachers' approach to problems was tried to be measured in terms of various variables. Besides, it is possible to examine the meaning of the candidates' approaches in terms of educational activities and make some suggestions against the wrong behaviors that pre-service teachers may display according to their cognitive styles. In this context, the purpose of the research is as follows.

\subsection{Purpose of the research}

The primary purpose of the study is to determine how prospective teachers think and act while finding solutions to the problems in their daily lives, whether they differ according to their cognitive style, gender, grade level, and departments, and to make suggestions about their approaches to the problems they may encounter while performing their teaching duties. In this direction, the questions given below will be tried to be answered:

(1) Is there a relationship between pre-service teachers' cognitive styles and their perception of problem-solving skills?

(2) Is there a relationship between pre-service teachers' gender and their perception of problem-solving skills?

(3) Is there a relationship between pre-service teachers' grade level and their perception of problem-solving skills?

(4) Is there a relationship between pre-service teachers' departments in which they study and their perception of problem-solving skills?

When analyzed literature related to the studies carried out in Turkey problem solving, perception is often seen to work towards (Demirtas \& Dönmez, 2008; Captain \& Korkmaz, 2002; Butcher, 1989; Soyer \& Scholar, 2010; Taylor, 1990; Yalcin, Trigger \& Açlkgöz 2010). When the studies on cognitive styles are examined, many studies stand out again, and among these studies, there are also studies conducted with field dependent and field independent cognitive styles (Boz, 1987; Çakan, 2005; Çıkrıkçı, 1990; Dinçer, 1993; Somyürek, 2004. Horzum \& Alper, 2006). At the beginning of the studies on the perception of problem-solving skills in the foreign field, the studies conducted by Heppener and Petersen (1982), Heppener and Anderson (1985), Larson and Heppener (1989), Jerath, Hasija and Malhotra (1993) and Ho (1981) countable. Although it is possible to find many studies on field-dependent and independent cognitive styles, the most common of these are the studies by Witkin et al. (1977) and Witkin and Goodenhough (1981), and Miller (1995), Weller and Weller (1993), Wey and Waugh (1993), Saracho (1988) and Shade (1983).

However, the most recent studies on the subject investigated in this study, including the studies other than those mentioned above, are made by Soyer and Bilgin (2010) and Ho (1981). 
Soyer and Bilgin (2010), in a study conducted with 551 university students, examined whether the problem-solving skill perception differs according to gender, age groups, and grade level attended and found that the difference was significant only by departments. In the other study, the gender, gender role type, and problem skills of 95 children between the ages of 8-10 were examined, and it was found that problem-solving skills differed according to gender role type (Ho, 1981). However, one of the aims of this study was to find no study on whether the fielddependent/independent cognitive style made a difference in the pre-service teachers' perception of problem-solving skills.

\section{Method}

The study was modelled according to the quantitative research method. Relationships between data were carried out with the relational questionnaire model. With this model, predictions can be provided for high-level data in research (Büyüköztürk, 2016: 185). In addition, relationships and the level of relations are determined with the mentioned model (Karasar, 2016: 114).

\subsection{Population and sample}

The population of this study includes the Faculty of Education students studying in Turkey. The study sample consists of 297 teacher candidates studying in the first and fourth grades of primary education, social Studies Education, Preschool Education, and the Turkish Education department of the Faculty of Education at Afyon Kocatepe University in the province of Afyon in Turkey. Candidates are determined voluntarily.

\subsection{Data collection tools}

\subsubsection{Group Embedded Figures Test (GSFT) - Group Embedded Figures Test}

In the study, GSFT developed by Witkin et al. (1971) was used to determine pre-service teachers' cognitive styles. It was adapted into Turkish by Çakan (2005). The test includes items that require individuals to find and draw on the 8 simple shapes given, on 25 figures consisting of 3 sections hidden in them and consist of 3 parts ordered from easy to difficult. The seven items in the first section are for practice purposes. There are nine items in each of the other two sections. The correct numbers obtained in the two sections represent the raw score. The teacher candidates' scores are grouped as field-independent for the top 27\% and area dependent for the bottom 27\% (Cureton, 1957, as cited in Çakan, 2005). In the adaptation to Turkish by Çakan (2005), test-retest reliability was determined as 0.82 for the total participant, 0.84 for men $(\mathrm{N}=179)$, and 0.81 for women $(\mathrm{N}=354)$.

\subsubsection{Problem Solving Inventory (PSI)}

In the study, PSI developed by Heppner and Peterson (1982) was used to determine pre-service teachers' problem-solving skills. The scale was adapted to Turkish by Şahin, Şahin, and Heppner (1993). It consists of 35 items. It is a Likert-type scale that is scored between 1-6. It is used to measure individual problem-solving perception. The lowest score of 32 and the highest 192 points can be obtained, and reverse scoring is done. In other words, a high score indicates a low perception of problem-solving. Items 9, 22, and 29 are not included in the assessment. Also, item in size 1, 2, 3, 4, 11, 13, 14, 15, 17, 21, 25, 26, 30 and 34 numbered operated in reverse in the scoring. It was assumed that the scale items adequately measure problem-solving perceptions at 
the individual level (Savaşır \& Şahin, 1997). Besides, a personal information form was used to obtain information about the gender, department, and grade levels.

\subsection{Data collection and analysis}

This study was carried out with 297 teacher candidates. GSFT was applied first, and since the test had to be applied in a limited time frame, the time frame allocated to each section was followed, and care was taken to ensure that the teacher candidates comply with the time allowed for the sections. In the test consisting of three parts in total, a 2-minute time frame was given for the first part, and this part consisting of 7 shapes was applied for trial purposes due to the nature of the test. The second and third sections contain nine figures each, and the time allotted for them is 5 minutes. Within these periods, it was determined that the candidates were in the field-dependent or field-independent group according to the number of figures they drew (o-18). For this, the arithmetic mean of the scores was calculated, and the candidates who scored below the average were grouped independently. In this study, the average score was calculated as 4.99. Candidates with a score of 5 and less than five were evaluated as field-dependent, who scored above 5 (6-18) were evaluated field independently.

Later, PSI was applied to determine the perceptions of pre-service teachers towards problem-solving skills. While the test-retest reliability coefficients of PSI were measured between $\mathrm{r}=.83$ and $\mathrm{r}=.89$, the Cronbach Alpha coefficient was found to be .88 , and the reliability coefficient was $r=.81$ (Saraçoğlu, Serin \& Bozkurt, 2005). The scale consists of three factors, "Trust in problem solving ability" (Items 5, 10, 11, 12, 19, 23, 24, 27, 33, 34 and 35), "Approach-avoidance" (1, 2, 4, 6, 7, 8, 13, 15, 16, 17, 18, 20, 21, 28, 30 and 31), and "Personal control" (Items 3, 14, 25, 26 and 32). As a result of the factor analysis, six factors were found as "Hasty Approach" (Items 13, 14, 15, 17, 21, 25, 26, 30 and 32), "Thinking Approach" (Items 18, 20, 31, 33 and 35), "Avoidant Approach" (Articles 1, 2, 3 and 4), "Evaluative Approach" (Articles 6, 7 and 8) "Self-Confident Approach" (Articles 5, 23, 24, 27, 28 and 34), and "Point Approach" (items 10, 12, 16 and 19) (Savaşır \& Şahin, 1997).

Both practices were applied during the course hours of the teacher candidates and by the researcher. The teacher candidates participating in the study were voluntarily included in the study sample, and data forms that were not by the principles of data collection tools were excluded from the study.

Some studies show that GEFT can be considered an achievement test (Crandall \& Sinkeldam, 1964). In the implementation phase of this study, there were reactions that pre-service teachers had such a perception. For this reason, it was stated to the candidates who participated in the study that this was not an achievement test, finding and drawing the figures or otherwise determined only the cognitive style. Also, it was emphasized that cognitive styles do not have superiority to each other but only determine how to approach events and problems.

\section{Results}

Work on the findings based, the frequency and percentage distribution of the preservice teachers participating in the study and the scores obtained by the candidates from PSI and its sub-dimensions according to their cognitive styles, gender, department, and class are given below. Accordingly, Independent Sample T-test was applied to examine the perceptions of preservice teachers' problem-solving skills and the six sub-dimensions of these perceptions determined by Savaşır and Şahin (1997) terms of whether there is a significant difference between cognitive styles, gender, and grade level. Also, the PSI scores' situation making a significant difference according to the departments was investigated by the One-Way Anova test. 
According to Table 1, 211 of the study participants are females (71\%), and 86 are males (29\%). In other words, approximately $3 / 4$ of the candidates are women.

Table 1. Teachers' percent by gender and frequency distribution categories

\begin{tabular}{lcc}
\hline Gender & $\mathbf{N}$ & $\mathbf{\%}$ \\
\hline Female & 211 & 71 \\
Male & 86 & 29 \\
\hline Total & 297 & 100 \\
\hline
\end{tabular}

Figure 2. Distribution of teacher candidates by gender

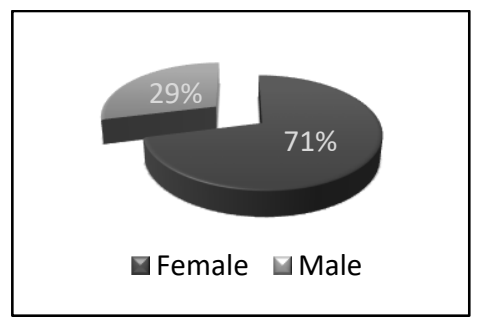

When Table 2 is examined, the candidates were selected from the departments with students in the first and fourth years of the faculty. The highest attendance took place in the Primary Education department with a total of 112 candidates (37.7\%), including 58 first-year students (19.5\%) and 54 fourth-year students (18.2\%). The minor participation was from the Social Studies Education department with a total of 53 candidates (17.7\%), 30 first grade students (10.1\%), and 23 fourth grade students (7.7\%). A total of 71 candidates (23.9\%) from the other two departments, 32 first grade (10.8\%) and 39 fourth grade $(13.1 \%)$ from the Preschool Education department, participated in the study, while 32 from the Turkish Education department were in the first grade (10.8\%), and 29 fourth-year students (9.7\%), a total of 61 candidates (20.5\%) attended.

Table 2. Percentage and frequencies of pre-service teachers according to their departments

\begin{tabular}{lccc}
\hline Department & Grade Level & N & \% \\
\hline Primary & $\mathbf{1}$ & 58 & 19.5 \\
Education & 4 & 54 & 18.2 \\
Social Studies & 1 & 30 & 10.1 \\
Education & 4 & 23 & 7.7 \\
Preschool & 1 & 32 & 10.8 \\
Education & 4 & 39 & 13.1 \\
Turkish & 1 & 32 & 10.8 \\
Education & 4 & 29 & 9.7 \\
\hline Total & & 297 & 100 \\
\hline
\end{tabular}

Figure 3. According to the department of teacher candidates' distribution

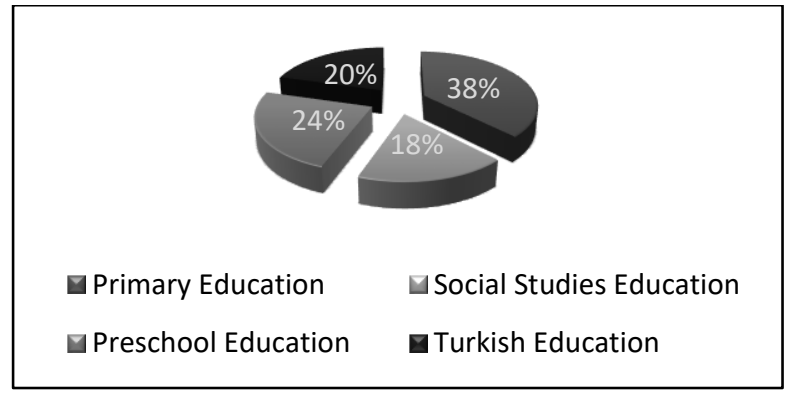


As it is known, the scores obtained from PSI indicate that the level of proximity to the minimum score is high on problem skills, and on the contrary, the perception decreases. For this reason, the data regarding the PSI total score were evaluated according to the average score (32 minimum, 192 maximum, the average score value is 112) that can be obtained in the PSI score. According to the data in Table 3, the average score the candidates got from PSI was calculated as 88.60. This situation shows that the candidates' perception of problem-solving skills is high. When the sub-dimensions are examined, the candidates' average scores in all sub-dimensions are close to or lower than the average scores that can be obtained. This situation shows the perception that candidates have these approaches in all sub-dimensions.

Table 3. Pre-service teachers' score analysis of PSI and its sub-dimensions

\begin{tabular}{lcccc}
\hline PSI Dimension I & $\begin{array}{l}\text { Score } \\
\text { Range }\end{array}$ & $\mathbf{X}$ & $\begin{array}{c}\text { Lowest } \\
\text { Score }\end{array}$ & Highest Score \\
\hline Hasty Approach & $9-54$ & 28.95 & 14 & 44 \\
Thinking Approach & $5-30$ & 12.55 & 5 & 30 \\
Avoiding Approach & $4-24$ & 10.63 & 4 & 24 \\
Evaluating Approach. & $3-18$ & 7.81 & 3 & 18 \\
Self-Confident Approach & $6-36$ & 15.92 & 6 & 35 \\
Planned Approx. & $4-24$ & 9.80 & 4 & 22 \\
\hline PSI Total Score & $32-192$ & 88.60 & 47 & 152 \\
\hline
\end{tabular}

4. Discussion

(1) Is there a relationship between pre-service teachers' cognitive styles and their perception of problem-solving skills?

When the scores obtained from PSI were examined in terms of the candidates' cognitive styles, Table 4 was obtained.

Table 4. PSI score analysis according to cognitive styles of pre-service teachers

\begin{tabular}{|c|c|c|c|c|}
\hline PSI & Cognitive Style & $\mathbf{p}$ & $\mathbf{N}$ & $\%$ \\
\hline \multirow{2}{*}{ PSI Total } & Field Dependent & \multirow{2}{*}{0.51} & \multirow{7}{*}{ Field Dependent } & \multirow{7}{*}{60.6} \\
\hline & Field Independent & & & \\
\hline \multirow{2}{*}{ Hurry Approach } & Field Dependent & \multirow{2}{*}{0.383} & & \\
\hline & Field Independent & & & \\
\hline \multirow{2}{*}{ Thinking Approach } & Field Dependent & \multirow{2}{*}{0.189} & & \\
\hline & Field Independent & & & \\
\hline \multirow{2}{*}{ Avoiding Approach } & Field Dependent & \multirow{2}{*}{0.618} & & \\
\hline & Field Independent & & & \multirow{7}{*}{39.4} \\
\hline \multirow{2}{*}{ Reviewed Approach } & Field Dependent & \multirow{2}{*}{0.13} & & \\
\hline & Field Independent & & & \\
\hline \multirow{2}{*}{ Confident Approach } & Field Dependent & \multirow{2}{*}{0.1} & Independent & \\
\hline & Field Independent & & & \\
\hline \multirow{2}{*}{ Planned Approach } & Field Dependent & \multirow{2}{*}{0.192} & 117 & \\
\hline & Field Independent & & & \\
\hline
\end{tabular}

As shown in Table 4, there is no statistically significant difference between the scores of PSI and sub-domains of individuals with field-dependent and field-independent cognitive styles $(\mathrm{p}>0.05)$. 
(2) Is there a relationship between pre-service teachers' gender and their perception of problem-solving skills?

Table 5 is obtained when the pre-service teachers' PSI and sub-dimension scores according to gender were analyzed.

Table 5. PSI score analysis according to cognitive styles of pre-service teachers

\begin{tabular}{|c|c|c|c|c|}
\hline$\overline{\text { PSI }}$ & Gender & $\mathbf{p}$ & $\mathbf{N}$ & $\%$ \\
\hline \multirow{2}{*}{ PSI Total } & Female & \multirow{2}{*}{0.868} & \multirow{4}{*}{ Bayan } & \multirow{7}{*}{71} \\
\hline & Male & & & \\
\hline Hurry Approach & Female & \multirow{2}{*}{0.167} & & \\
\hline & Male & & & \\
\hline Thinking Approach & Female & \multirow{2}{*}{0.831} & \multirow[t]{2}{*}{211} & \\
\hline & Male & & & \\
\hline \multirow[t]{2}{*}{ Avoiding Approach } & Female & \multirow{2}{*}{0.470} & & \\
\hline & Male & & \multirow{4}{*}{ Erkek } & \multirow{7}{*}{29} \\
\hline \multirow[t]{2}{*}{ Reviewed Approach } & Female & \multirow{2}{*}{0.836} & & \\
\hline & Male & & & \\
\hline Confident Approach & Female & \multirow{2}{*}{0.483} & & \\
\hline \multirow{3}{*}{ Planned Approach } & Male & & 86 & \\
\hline & Female & \multirow{2}{*}{0.707} & & \\
\hline & Male & & & \\
\hline
\end{tabular}

According to the data in Table 5, no statistical significance was found in the scores of 211 female teacher candidates (71\%) and 86 male teacher candidates (29\%) in PSI and its subdimensions.

(3) Is there a relationship between pre-service teachers' grade level and their perception of problem-solving skills?

In Table 6, the significance between the scores that first-grade and fourth-grade students got from PSI and sub-domains is analyzed.

Table 6. PSI score analysis of pre-service teachers according to their grade levels

\begin{tabular}{lcccc}
\hline PSI & Grade Levels & p & N & \% \\
\hline PSI Total & 1 & 0.001 & & \\
Hasty Approach & 4 & & & \\
Thinking Approach & 1 & 0.003 & $1^{\text {st }}$ Grade & \\
Avoiding Approach & 4 & 0.001 & 152 & \\
Reviewed Approach & 4 & & & 48,8 \\
Confident Approach & 1 & 0.545 & & \\
Planned Approach & 1 & 0.000 & & \\
\hline
\end{tabular}

According to the data obtained from Table 6, the scores the students got from the PSI total and hasty approach, thinking approach, evaluative approach, and planned approach sub- 
dimensions were found to be statistically significant according to $\mathrm{p}<0.05$. Besides, when the scores of the avoidant approach and self-confident approach sub-dimensions were examined, it was observed that there were no significant differences in these areas according to the grade level.

(4) Is there a relationship between pre-service teachers' departments in which they study and their perception of problem-solving skills?

Another comparison was made between PSI and its sub-dimensions at the departmental level. One-Way ANOVA test was used here. The data obtained are as shown in Table 7 .

Table 7. PSI Score Analysis of Pre-Service Teachers According to their Departments

\begin{tabular}{|c|c|c|c|c|}
\hline Point Type & $\mathbf{p}$ & Point Type & $\begin{array}{c}\text { Difference Between } \\
\text { Departments }\end{array}$ & $\mathbf{X}$ \\
\hline PSI Total & 0.2 & \multirow{2}{*}{ Avoidant } & Primary Education- & \multirow{2}{*}{1.627} \\
\hline Hurry Approach & 0.47 & & Turkish Education & \\
\hline $\begin{array}{l}\text { Thinking } \\
\text { Approach }\end{array}$ & 0.206 & \multirow{2}{*}{ Planned } & Primary Education- & \multirow{2}{*}{2.063} \\
\hline $\begin{array}{l}\text { Avoiding } \\
\text { Approach }\end{array}$ & 0.045 & & Social Studies Education & \\
\hline $\begin{array}{l}\text { Thinking } \\
\text { Approach }\end{array}$ & 0.491 & \multirow{3}{*}{ Planned } & Turkish Education & \multirow{3}{*}{1.663} \\
\hline $\begin{array}{l}\text { Confident } \\
\text { Approach }\end{array}$ & 0.136 & & Social Studies Education & \\
\hline $\begin{array}{l}\text { Planned } \\
\text { Approach }\end{array}$ & 0.004 & & & \\
\hline
\end{tabular}

According to the data presented in Table 7, the difference between the departments in which the candidates were educated was observed in the avoidant approach (0.045) and the planned approach (0.004) sub-dimensions $(\mathrm{p}<0.05)$. When the departments differ in these subdimensions, there is a significant difference in favor of Primary Education in the avoidant approach sub-dimension between Primary Education and Turkish Education. In the planned approach sub-dimension, a significant difference was observed between Primary Education and Turkish education in favor of Primary Education and Turkish Education and Social Studies Education in favor of Turkish education.

\section{Conclusion}

In this study, the results obtained from the tests performed on a sample of mostly female students can be addressed in 4 items:

(1) It has been revealed that there is no statistically significant difference between the scores of the pre-service teachers in PSI and its sub-dimensions of field-dependent and fieldindependent ones. This situation can be interpreted as problem-solving perception is not affected by way of approaching the problem. Even when the problems are approached in different ways, it can be concluded that the perceptions are not related to the approach.

(2) In the analysis conducted to measure the effect of pre-service teachers' being male or female on problem-solving perception, no statistical significance was found between males and females. In this case, it can be concluded that the perception of problem-solving skills is not related to gender since there are no data directly related to gender in the perceptions of men and women regarding problem-solving skills. 
(3) The statistical difference between the scores of PSI total and hasty approach, thinking approach, evaluative approach, and planned approach sub-dimensions showed that students' perceptions might change in different dimensions depending on the grade level.

(4) The statistical difference regarding the problem-solving skill perception among the departments they study in can be interpreted as classroom teacher candidates' problem-solving perceptions are more confident than students studying in Turkish education and social studies education. A similar situation is observed between Turkish education and social studies education, and it can be said that Turkish Education students' perceptions are more favorable than social studies education.

In this study, first and $4^{\text {th }}$-year students were included in the study sample to determine the difference between grade levels at the highest level. Studies can be carried out to examine problem situations such as how problem-solving skills perceptions develop among grade levels, whether this changes with the education given at the university, or whether any variable is a factor. Besides, the reasons for the differences arising between departments can be investigated. While determining the sample of this study, students were selected at the 1 st and $4^{\text {th }}$-grade levels, and there was no other department at the 4th grade except for the four departments included in the study in the education faculty of the university where the study was conducted, so other fields in education faculties were not included in the study. For this reason, these studies can be carried out on the students of education faculties where other departments are located.

\section{Acknowledgements}

This research did not receive any specific grant from funding agencies in the public commercial, or not-for-profit sectors.

The author declares no competing interests.

\section{References}

Altun, A. (2003). Examining the relationship between teacher candidates' cognitive styles and their attitudes towards computers. The Turkish Online Journal of Educatioanal Technology, 2(1), 56-62.

Altun, M. (2000). Teaching problem solving in primary education. Journal of Milli Eğitim. http://dhgm.meb.gov.tr/yayimlar/dergiler/Milli Egitim Dergisi/147/altun.htm.

Ataizi, M. (1999). The effects of cognitive style and authenticity level on development of problem solving skills during computer-based situated learning (Unpublished $\mathrm{PhD}$ Thesis). Anadolu University/Social Scientes Institute, Eskişehir.

Boz, Y. (1987). Evaluation of addiction and field independence dimension from cognitive styles from 5-12 years old hearing-impaired students attending Eskişehir Anadolu University Hearing Impaired Children Education Center (Unpublished Master Thesis). Anadolu University/Social Scientes Institute, Eskişehir.

Büyüköztürk, Ş. (2016). Multivariate Statistics for Social Sciences SPSS and LISREL Applications. Ankara: Pegem Akademi Publishing.

Crandall, J. V., \& Sinkeldam, C. (1964). Children's dependent and achievement behaviors in social situations and their perceptual field dependence. Journal of Personality, 32, 1-22. http://doi.org/10.1111/j.1467-6494.1964.tb01322.x. PMID: 14132503. 
M. Keskin - Comparison of Prospective Teachers' Perceptions of Problem-Solving Skills...

Çakan, M. (2003). Psychometric data on the group embedded figures test for Turkish undergraduate students. Perceptual and Motor skills, 96(3), 993-1004.

http://doi.org/10.2466/pms.2003.96.3.993

Çakan, M. (2005). Relationship between second language proficiency and cognitive styles: example of 8th grade French. Elementary Education Online, 4(1). Retrieved from http://ilkogretimonline.org.tr/index.php/io/article/view/2023/1859.

Çlkrıkçı, N. (1990). The effect of negative anticipation and cognitive style on mental performance. (Unpublished Master Thesis). Ankara University/Social Sciences Institute, Ankara.

Demirtaş, H., \& Dönmez, B. (2008). Secondary school teachers' perceptions about their problem solving abilities. İnönü University, Journal of the Faculty of Education, 9(16), 177-198. Retrieved from https://dergipark.org.tr/tr/pub/inuefd/issue/8707/108713.

Dinçer, Z. (1993). The impact of socio-economic level on cognitive styles (Unpublished Master Thesis). Ankara University/Social Sciences Institute, Ankara.

Güven, B. (2003). The effect of teaching activities designed for field dependet and independent students on their academic achievement and attitudes in the $5^{\text {th }}$ grade of the social studies course in elementary school (Unpublished PhD Thesis). Anadolu University/Educational Sciences Institute, Eskişehir.

Heppener, P. P., \& Anderson, W. P. (1985). The relationship between problem solving self-appraisal and psychological adjustment. Cogn Ther Res, 9, 415-427. https://doi.org/10.1007/BFo1173090

Heppener, P. P., \& Peterson, C. H. (1982). The development and implications of a personal problem solving invetory. Journal of Counseling Psychology, 29(1), 66-75. http://doi.org/10.1037/00220167.29.1.66

Ho, R. (1981) Sex, sex-role typing, and children's problem-solving behavior. The Journal of Social Psychology, 115(2), 219-226, http://doi.org/10.1080/00224545.1981.9711661

Horzum, M. B., \& Alper, A. (2006). The effect of case based learning model, cognitive style and gender to the student achievement in science courses. Ankara University, Journal of Faculty of Educational Sciences, 39(2), 151-175.

Jrath, J. M., Hasija, S., \& Malhotra, D. (1993). A study of state anxiety scores in a problem solving situation. A study of state anxiety scores in a problem solving situation. Studia Psychologica, 35(2), 143149.

Karasar, N. (2016). Scientific research method: Concepts, principles, techniques (30 ${ }^{\text {th }}$ Edition). Ankara: Nobel Publishing.

Kaptan, F., \& Korkmaz, H. (2002). A study on the perception towards to pre-service teachers' problem solving skills. Journal of Qafqaz University, 9(1), 183-188.

Kasap, Z. (1989). The relation between success and manner of primary school 4th year students in problem solving according to the socio-economic level (Unpublished Master Thesis). Marmara University/Educational Scientes Institute, İstanbul.

Larson, L. M., \& Heppener, P. P. (1989). Problem solving appraisal in an alcoholic population. Journal of Counseling Psychology, 36(1), 73-78. https://doi.org/10.1037/0022-0167.36.1.73

Mertoğlu, H., \& Öztuna, A. (2004). Is the use of technology of individuals related to their problem solving abilities? The Turkish Online Journal of Educational Technology, 3(1), 83-92. Retrieved from http://www.tojet.net/articles/v3i1/3112.pdf.

Miller, G. (1995). Learning style of agricultural distance learners. NAERM (Dec1, 1995).

Ören, D. (2007). An investigation of 1oth grade students' proof schemes in geometry with respect to their cognitive styles and gender (Unpublished Master Thesis). Middle East Technical University/ Graduate School of Natural and Applied Sciences, Ankara. 
Ramirez, A. I., \& Castenada, A. (1974). Cultural democracy, bicognitive development and education. Academic Press.

Saracaoğlu, A. S., Serin, O., \& Bozkurt, N. (2005). Examination of problem solving and locus of control levels of graduate students of educational sciences institute in terms of some variables. Dokuz Eylül University, Journal of Buca Faculty of Education, 17. Retrieved from https://dergipark.org.tr/tr/pub/deubefd/issue/25433/268368.

Saracho, O. N. (1988). Cognitive styles and young children's learning. Early Child Development and Care, 3O(1-4), 213-220, http://doi.org/10.1080/0300443880300118

Savaşır, I., \& Şahin, H. N. (1997). Assessment in cognitive-behavioral therapy: frequently used scales. Ankara: Turkish Psychologists Association Publications.

Shade, J. B. (1983). Cognitive strategies as determinants of school achievements. Psychology in the Schools, 2O(4), 488-493. https://doi.org/10.1002/1520-6807(198310)20:4<488::AIDPITS2310200416>3.0.CO;2-U

Somyürek, S. (2004). The effects of advance organizers existing in computer assisted instruction software on achievement of the field dependent and field independent students. (Unpublished Master Thesis). Gazi University / Educational Sciences Institute, Ankara.

Somyürek, S., \& Yalın, H. İ. (2007). The effect of pre-organizers used in computer-aided educational software on academic achievement of field dependent and independent students. Turkish Journal of Educational Sciences, 5(4), 587-607. Retrieved from https://dergipark.org.tr/tr/pub/tebd/issue/26114/275121.

Soyer, M. K., \& Bilgin, A. (2010). Problem- solving skills perceptions of the university students according to different variants. International Conference on New Trends in Education and Their Implications. Antalya (November 11-13).

Şahin, N., Şahin, N., \& Heppener, P. P. (1993). Psychometric properties of the problem solving inventory in a group of Turkish university students. Cogn Ther Res, 17, 379-396. https://doi.org/10.1007/BFo1177661

Taylan, S. (1990). Adaptation, reliability and validity studies of Heppner's problem solving inventory. (Unpublished Master Thesis). Ankara University/ Social Sciences Insttitute, Ankara.

Weller, R., \& Weller, L. (1993). The effects of cognitive styles and learning strategy in a hypermedia environment. The Computer Ethics Stack.

Wey, P., \& Waugh, M. L. (1993). The effects of different interface presentation modes and users' individual differences on users' hypertext information access performance. Paper presented at the annual meeting of American Educational Research Association, Atlanta, GA.

Witkin, H. A., \& Goodenhough, D. R. (1981). Field dependent-independent. Journal of Educational Psychology, 75(5).

Witkin, H. A., Moore, C. A., Goodenough, D. R., \& Cox, P. W. (1977). Field dependent and field independent cognitive styles and their educational implications. Review of Educational Research, 47, 1-64.

Witkin, H. A., Oltman, P. K., Raskin, E., \& Karp, S. A. (1971). A manual for the group embedded figures test. Palo Alto, CA: Consulting Psychologists Press.

Yalçın, B., Tetik, S., \& Açıkgöz, A. (2010). A study on the determination of the perceptions of problem solving skills and the levels of locus of control of high school students. Journal of Organization and Management Sciences, 2(2), 19-27. Retrieved from https://dergipark.org.tr/tr/pub/oybd/issue/16336/171024. 
M. Keskin - Comparison of Prospective Teachers' Perceptions of Problem-Solving Skills...

C O A $\mathrm{s}$ 